\title{
Effect of Parity on Mineral and Vitamin Status of Holstein Cows during Early Lactation
}

\author{
Shin-ichi Kume, Eiji Yamamoto*, Teturo Kudo* \\ and Shinobu TANABE \\ National Institute of Animal Industry, Tsukuba Norin Kenkyu Danchi, \\ Ibaraki-ken 305 \\ ${ }^{*}$ Koibuchi College of Agriculture, Uchihara-machi, \\ Ibaraki-ken 319-03
}

(Received November 8, 1994)

\begin{abstract}
Milk and plasma samples from 4 primiparous and 4 multiparous Holstein cows were collected for 10 weeks after parturition to clarify the effects of parity on the mineral and vitarnin status of dairy cows during the period of parturition to early lactation. Colostrai $\mathrm{Ca}, \mathrm{P}$, vitamin $A$ and $\beta$-carotene concentrations as well as those concentrations in plasma were higher in primiparous cows than in multiparous cows at parturition. Although colostral $\mathrm{Zn}$ concentration of primiparous cows was higher than that of multiparous cows, plasma $\mathrm{Zn}$ of primiparous cows was lower. There was a similar trend in plasma $\mathrm{Ca}, \mathrm{Fe}$, and $\mathrm{Zn}$ with parity at birth and early lactation, but there was a reverse trend for $\mathrm{Ca}$ and vitamin $\mathrm{A}$ in milk, and plasma vitamin $\mathrm{A}$ and $\beta$-carotene in primiparous and multiparous cows at birth and early lactation. There was no distinct trend in the change of plasma mineral concentrations during early lactation, while plasma vitamin $A$ and $\beta$-carotene concentrations of multiparous cows increased drastically from parturition to early lactation.
\end{abstract}

Anim. Sci. Technol. (Jpn.) 66 (6) : 506-512, 1995

Key words : dairy cattle, early lactation, mineral, vitamin

Dairy cattle secrete large quantities of minerals and vitamins into milk during the period of parturition to early lactation. As a result, disturbances in mineral and vitamin metabolism, such as milk fever and grass tetany, are often observed at early lactation ${ }^{10)}$. Also, some metabolic and reproductive disorders are related to the imbalances of minerals and vitamins in dairy cows around parturition to early lactation $2,4,5,9,10)$.

Mineral and vitamin status of dairy cows varies with a number of factors. Lactation number is a factor responsible for the changes in the mineral and vitamin concentration of colostrum or milk and their nutritional status in postpartum cows ${ }^{3,7,8)}$. However, the relationship between mineral and vitamin removal in colostrum or milk and their status in plasma after parturition has not been well clarified in primiparous and multiparous cows. The objective of this study is to investigate the effects of parity on the mineral and vitamin status of dairy cows during the period of parturition to early lactation.

\section{Materials and Methods}

Data from 4 primiparous and 4 multiparous Holstein cows kept at Koibuchi College of Agriculture were collected for 10 weeks after parturition from November 1993 to March 1994. 
Cows were managed under similar conditions during the experimental period to meet nutrient requirement of daily cattle ${ }^{1)}$ for TDN, protein, and minerals. Cows were fed $3 \mathrm{~kg}$ of concentrate, $10 \mathrm{~kg}$ of corn silage, and oat hay for ad libitum intake during the dry period (Table 1). During the period of parturition to early lactation, cows were fed mainly mixed rations, which consisted of $20 \%$ of concentrate, $10 \%$ of beet pulp, $3 \%$ of cottonseed, $4 \%$ of Lucerne hay, $17 \%$ of Sudangrass hay, and $40 \%$ of corn silage. Vitamin $\mathrm{A}$ and $\beta$-carotene concentrations in feed were not determined, but approximately $10,000 \mathrm{IU} / \mathrm{kg}$ of vitamin A was added in mixed rations from vitamin premix.

Each cow was milked immediately after parturition and at 0500 and $1500 \mathrm{~h}$ postpartum. Milk weights were recorded daily. Colostrum samples were collected at parturition and milk samples were collected at equal intervals of 7 days from 1 to 10 weeks postpartum. Milk was a composite sample of morning and evening milking. Blood samples were obtained by jugular puncture into heparinized vacuum tubes at $1100 \mathrm{~h}$ on the same day as milk collection and centrifuged immediately after collection. Plasma and milk samples were frozen at $-20^{\circ} \mathrm{C}$ until they were analyzed for minerals and vitamins.

Colostrum composition and the concentrations of plasma $\mathrm{Ca}$, inorganic $\mathrm{P}(\mathrm{Pi}), \mathrm{Mg}$, vita$\min \mathrm{A}$, and $\beta$-carotene were determined as described previously ${ }^{7,8)}$. The concentrations of plasma $\mathrm{Fe}, \mathrm{Zn}$, and $\mathrm{Cu}$ were determined by atomic absorption spectrophotometry after dilution with distilled water.

The general linear models procedure of SAS $^{(1)}$ was used to analyze the effect of parity on blood and colostrum composition of cows at parturition. Data from 1 to 10 weeks postpartum were analyzed by least squares ANOVA using the general linear models procedure of SAS ${ }^{11}$. The model was as follows;

$$
\mathrm{Y}_{\mathrm{ijk}}=\mu+\mathrm{P}_{\mathrm{i}}+\mathrm{C}_{(\mathrm{i}) \mathrm{j}}+\mathrm{T}_{\mathrm{k}}+\mathrm{PT}_{\mathrm{ik}}+\mathrm{e}_{\mathrm{ijk}}
$$

where

$\mu=$ overall mean,

$\mathrm{P}_{\mathrm{i}}=$ effect of parity,

$\mathrm{C}_{[i \mathrm{j} j}=$ cows, random variable nested in parity,

$\mathrm{T}_{\mathrm{k}}=$ effect of sampling time,

$\mathrm{PT}_{\mathrm{ik}}=$ interactions, and

$\mathrm{e}_{\mathrm{ijk}}=$ residuals.

Significance was declared at $P<0.05$ unless otherwise noted.

\section{Results}

There were no metabolic and reproductive

Table 1. Chemical composition of feedstuff

\begin{tabular}{lcccr}
\hline \hline & $\begin{array}{c}\text { Mixed } \\
\text { ration }\end{array}$ & Concentrate & $\begin{array}{c}\text { Corn } \\
\text { silage }\end{array}$ & $\begin{array}{c}\text { Oat } \\
\text { hay }\end{array}$ \\
\hline & & & & \\
DM & 59.90 & 87.04 & 19.94 & 89.26 \\
$\mathrm{CP}$ & 15.94 & 20.47 & 7.72 & 11.05 \\
$\mathrm{Crude}$ fat & 4.70 & 3.52 & 3.15 & 1.42 \\
$\mathrm{NDF}$ & 40.44 & 17.47 & 61.93 & 68.82 \\
$\mathrm{ADF}$ & 27.24 & 11.24 & 39.78 & 39.51 \\
$\mathrm{Ca}$ & 0.65 & 0.91 & 0.22 & 0.35 \\
$\mathrm{P}$ & 0.39 & 0.74 & 0.25 & 0.28 \\
$\mathrm{Mg}$ & 0.27 & 0.33 & 0.13 & 0.13 \\
$\mathrm{Fe}$ & 167 & 123 & 336 & 3,105 \\
$\mathrm{Zn}$ & 29.6 & 51.2 & 18.5 & 20.0 \\
$\mathrm{Cu}$ & 8.2 & 12.2 & 8.6 & 11.4 \\
\hline
\end{tabular}


disorders in primiparous and multiparous cows during 10 weeks after parturition. However, at 4 months postpartum, abortion was observed in a primiparous cow and another primiparous cow died due to kidney disorder.

There were no significant differences in colostrum yield and colostral protein at birth (Table 2). Colostral $\mathrm{Ca}(P<0.01)$ and $\mathrm{P}$ concentrations as well as plasma $\mathrm{Ca}(P<0.01)$ and $\mathrm{Pi}$ $(P<0.01)$ were significantly higher in primiparous cows than in multiparous cows at parturition. Although colostral $\mathrm{Zn}$ concentration of primiparous cows was significantly $(P<0.01)$ higher than that of multiparous cows, plasma $\mathrm{Zn}$ concentration of primiparous cows was lower. Plasma Fe concentration of multiparous cows was significantly higher than that of primiparous cows, but there were no significant differences in $\mathrm{Mg}$ and $\mathrm{Cu}$ concentrations in colostrum and plasma. The concentrations of colostral vitamin $\mathrm{A}(P<0.001)$ and $\beta$-carotene $(P<0.001)$ as well as plasma vitamin $A$ and $\beta$-carotene $(P<0.01)$ of primiparous cows were significantly higher than those of multiparous cows.

Milk yield $(P<0.001)$ and milk protein of multiparous cows were significantly higher than those of primiparous cows during early lactation (Table 3). There was a similar trend in plasma $\mathrm{Ca}, \mathrm{Fe}$, and $\mathrm{Zn}$ with parity at birth and early lactation, but there was a reverse trend for $\mathrm{Ca}$ and vitamin $\mathrm{A}$ in milk, and plasma vitamin $A$ and $\beta$-carotene in primiparous and multiparous cows at birth and early lactation. Additionally, colostral $\mathrm{Mg}(P<0.001)$ and $\mathrm{Fe}$ or plasma $\mathrm{Mg}$ concentrations of primiparous cows were significantly lower than those of multiparous cows during early lactation, but plasma $\mathrm{Cu}$ of primiparous cows was higher.

Protein, $\mathrm{Ca}, \mathrm{P}$, vitamin $\mathrm{A}$ and $\beta$-carotene concentrations in milk during early lactation decreased until 5 weeks postpartum and, then, tended to increase gradually, while the highest milk yields were observed at 4 weeks postpartum. There was no distinct trend in the change of $\mathrm{Fe}, \mathrm{Zn}$ and $\mathrm{Cu}$ concentrations in milk and plasma mineral concentrations during early lactation, while there was a obvious trend

Table 2. Mineral and vitamin concentration of colostrum and plasma in primiparous and multiparous cows at parturition

\begin{tabular}{|c|c|c|c|c|c|c|}
\hline & \multicolumn{2}{|c|}{ Colostrum } & \multirow{2}{*}{ SEM } & \multicolumn{2}{|c|}{ Plasma } & \multirow{2}{*}{ SEM } \\
\hline & Primiparous & Multiparous & & Primiparous & Multiparous & \\
\hline $\mathrm{n}$ & 4 & 4 & & 4 & 4 & \\
\hline Age, mo. & $25.8^{\mathrm{d}}$ & 48. $1^{\mathrm{c}}$ & 2.9 & & & \\
\hline Milk yield, $\mathrm{kg} / \mathrm{d}$ & 2.0 & 2.8 & 0.9 & & & \\
\hline Protein, $\%$ & 14.8 & 14.0 & 0.9 & & & \\
\hline $\mathrm{Ca}, \mathrm{mg} / \mathrm{d} l$ & $284^{\circ}$ & $234^{d}$ & 7 & $10.9^{c}$ & 8. $9^{\mathrm{d}}$ & 0.3 \\
\hline $\mathrm{P}, \mathrm{mg} / \mathrm{d} l$ & $234^{\mathrm{a}}$ & $217^{b}$ & 4 & 6. $1^{1, c}$ & 4. $1^{1, \mathrm{~d}}$ & 0.3 \\
\hline $\mathrm{Mg}, \mathrm{mg} / \mathrm{d} l$ & 44.5 & 40.5 & 1.3 & 2. 18 & 2. 29 & 0.07 \\
\hline $\mathrm{Fe}, \mathrm{ppm}$ & 1.3 & 1.2 & 0.1 & $0.52^{b}$ & 1. $28^{a}$ & 0.15 \\
\hline $\mathrm{Zn}, \mathrm{ppm}$ & 25. $7^{\mathrm{c}}$ & 17. $5^{\mathrm{d}}$ & 1.4 & $0.32^{\mathrm{d}}$ & $0.57^{\circ}$ & 0.04 \\
\hline $\mathrm{Cu}, \mathrm{ppm}$ & 0.30 & 0.34 & 0.02 & 0.81 & 1.02 & 0.09 \\
\hline vitamin $\mathrm{A}, \mu \mathrm{g} / \mathrm{d} l$ & $377^{e}$ & $186^{f}$ & 16 & 28. $4^{\mathrm{a}}$ & $20.0^{\mathrm{b}}$ & 2.2 \\
\hline$\beta$-carotene, $\mu \mathrm{g} / \mathrm{d} l$ & $135^{\mathrm{e}}$ & $65^{f}$ & 7 & $234^{c}$ & $98^{d}$ & 19 \\
\hline
\end{tabular}

a.b Means within colostrum or plasma of same row with different superscript letters differ $(\mathrm{P}<0.05)$.

$c_{i}$ d Means within colostrum or plasma of same row with different superscript letters differ $(P<0.01)$.

$e_{1} f$ Means within colostrum or plasma of same row with different superscript letters differ $(\mathrm{P}<0.001)$.

${ }^{1}$ Inorganic P. 
Mineral and Vitamin Status of Cows

Table 3. Mineral and vitamin concentration of milk and plasma in primiparous and multiparous cows during 10 week after parturition

\begin{tabular}{|c|c|c|c|c|c|c|}
\hline & \multicolumn{2}{|c|}{ Milk } & \multirow{2}{*}{ SEM } & \multicolumn{2}{|c|}{ Plasma } & \multirow{2}{*}{ SEM } \\
\hline & Primiparous & Multiparous & & Primiparous & Multiparous & \\
\hline $\mathrm{n}$ & 40 & 40 & & 40 & 40 & \\
\hline Milk yield, $\mathrm{kg} / \mathrm{d}$ & $20.5^{t}$ & $29.2^{\mathrm{e}}$ & 0.4 & & & \\
\hline Protein, \% & $3.0^{\mathrm{b}}$ & $3.4^{\mathrm{a}}$ & 0.1 & & & \\
\hline $\mathrm{Ca}, \mathrm{mg} / \mathrm{d} l$ & $112^{\mathrm{d}}$ & $117^{\mathrm{c}}$ & 1 & $10.8^{\mathrm{e}}$ & 9. $9^{f}$ & 0.1 \\
\hline $\mathrm{P}, \mathrm{mg} / \mathrm{d} l$ & 89 & 91 & 1 & $5.2^{1}$ & $5.5^{1}$ & 0.1 \\
\hline $\mathrm{Mg}, \mathrm{mg} / \mathrm{d} l$ & 9. $1^{f}$ & $10.7^{e}$ & 0.1 & 2. $36^{\mathrm{b}}$ & 2. $49^{\mathrm{a}}$ & 0.04 \\
\hline $\mathrm{Fe}, \mathrm{ppm}$ & $0.65^{\mathrm{b}}$ & $0.78^{\mathrm{a}}$ & 0.04 & 1. $10^{r}$ & 1. $34^{\mathrm{e}}$ & 0.04 \\
\hline Zn, ppm & 3.6 & 3.6 & 0.1 & $0.80^{f}$ & $0.92^{e}$ & 0.02 \\
\hline $\mathrm{Cu}, \mathrm{ppm}$ & 0.29 & 0.27 & 0.01 & 1. $00^{\mathrm{a}}$ & $0.92^{b}$ & 0.03 \\
\hline vitamin $\mathrm{A}, \mu \mathrm{g} / \mathrm{d} l$ & $27.0^{\mathrm{b}}$ & $31.3^{a}$ & 1.5 & 39. $0^{f}$ & $54.8^{e}$ & 0.9 \\
\hline$\beta$-carotene, $\mu \mathrm{g} / \mathrm{d} l$ & 7.2 & 8.0 & 0.5 & $185^{t}$ & $313^{e}$ & 8 \\
\hline
\end{tabular}

${ }^{a} b$ Means within milk or plasma of same row with different superscript letters differ $(P<0.05)$.

ad Means within milk or plasma of same row with different superscript letters differ $(\mathrm{P}<0.01)$.

e.f Means within milk or plasma of same row with different superscript letters differ $(\mathrm{P}<0.001)$.

${ }^{1}$ Inorganic $P$.

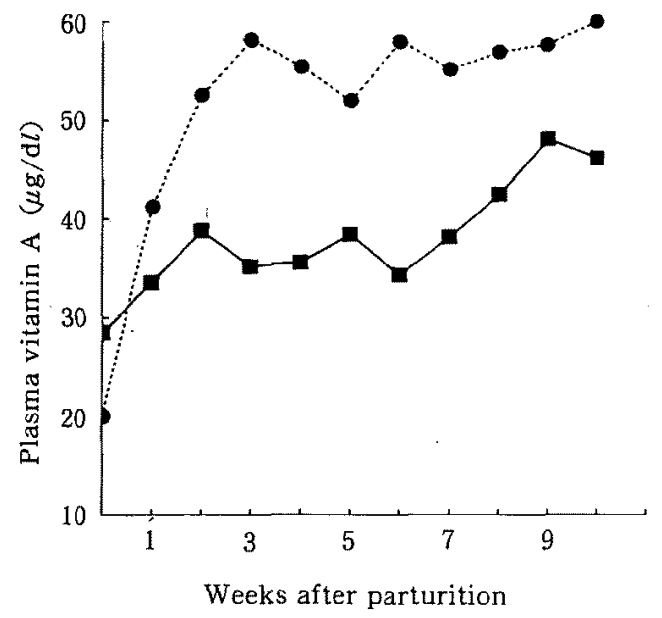

Fig. 1. Plasma vitamin A concentration of primiparous ( $\mathbf{O}$ ) and multiparous (O) cows during 10 week after parturition $(\mathrm{SEM}=3.0)$.

in the plasma vitamin $A$ and $\beta$-carotene with parity. Plasma vitamin A concentration of multiparous cows increased $(P<0.001)$ drastically from parturition to 4 weeks postpartum and remained constant, while the increase rate of plasma vitamin $A$ of primiparous cows was small (Fig. 1). Plasma $\beta$-carotene

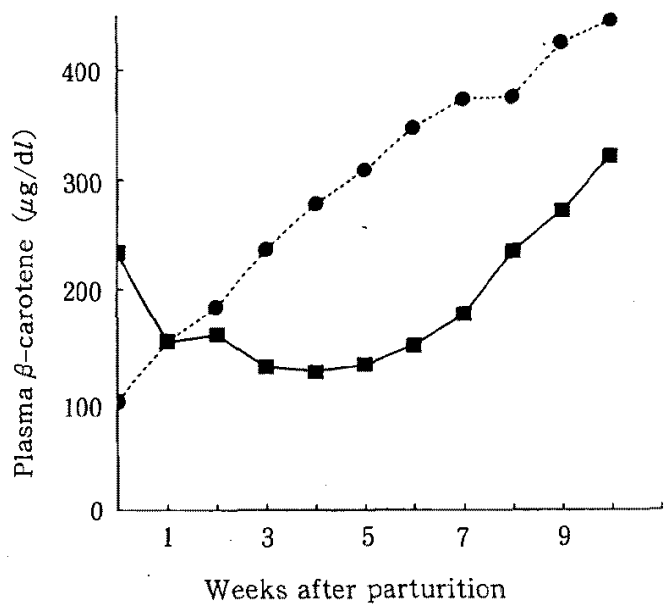

Fig. 2. Plasma $\beta$-carotene concentration of primiparous ( $\square$ ) and multiparous (O) cows during 10 week after parturition (SEM=24).

concentration of multiparous cows increased $(P<0.001)$ drastically from parturition to 10 weeks postpartum (Fig. 2). However, plasma $\beta$-carotene of primiparous cows decreased until 4 weeks postpartum and then increased $(P<0.001)$ drastically. 


\section{Discussion}

Most metabolic disorders occur at shortly after parturition and reflect a failure of the cow to adjust to the rapid onset and stress of high milk production ${ }^{10}$. Mineral and vitamin needs for lactating cows were enhanced after parturition because of their transfer to colostrum or milk. Kume et al. reported that the lowest fat, protein, $\mathrm{Ca}, \mathrm{P}$, and $\mathrm{Mg}$ concentrations in milk were observed at 5 weeks postpartum in contrast with the increase of milk yield ${ }^{6}$, which agree with the results of present experiment, including the changes in vitamin $A$ and $\beta$ carotene in milk.

Parity is a factor altering the mineral and vitamin status of dairy cows 3 ,4,7.8). Plasma Ca and $\mathrm{Pi}$ concentrations of dairy cows decreased around parturition because of the large transfer of $\mathrm{Ca}$ and $\mathrm{P}$ to colostrum, and older cows had a greater risk of developing milk fever ${ }^{4}$. However, we reported that $\mathrm{Ca}$ and $\mathrm{P}$ losses in colostrum at parturition tended to decrease after third lactation ${ }^{7}$. In the present experiment, plasma $\mathrm{Ca}$ and $\mathrm{Pi}$ of multiparous cows at parturition were lower than those of primiparous cows, and total $\mathrm{Ca}$ and $\mathrm{P}$ secretions in colostrum at parturition were slightly higher in multiparous cows. SHAPPELL et al. ${ }^{12)}$ reported that hypocalcemia and transfer of $\mathrm{Ca}$ to colostrum were not correlated. These results suggest that parity is the main factor for the development of milk fever due to the failure of rapid adaptation in $\mathrm{Ca}$ and $\mathrm{P}$ homeostasis, but further study is needed to clarify the relationship between $\mathrm{Ca}$ and $\mathrm{P}$ removal in colostrum and their status in plasma or bone at parturition.

Grass tetany is caused by inadequate $\mathrm{Mg}$ in critical extracellular fluids and older cows are more susceptible to grass tetany ${ }^{10)}$. In the present experiment, however, plasma $\mathrm{Mg}$ of multiparous cows during early lactation was higher than that of primiparous cows, although $\mathrm{Mg}$ secretion into milk of multiparous cows was greater. Also, plasma $\mathrm{Fe}$ and $\mathrm{Zn}$ of multiparous cows were higher than those of primiparous cows, while plasma $\mathrm{Ca}$ and $\mathrm{Cu}$ of multiparous cows were lower. Thus, although parity may be a factor altering mineral status of cows during early lactation, the relationship between mineral removal in milk and their status of cows were not well clarified in the present experiment.

The reverse relationships were observed for the concentrations of plasma vitamin $A$ and $\beta-$ carotene of primiparous and multiparous cows at parturition and early lactation, which coincided with the changes of those concentrations in milk. The biological function of $\beta$ carotene and other carotenoids is widely accepted to be independent of their provitamin A activity $^{2}$. In the present experiment, however, the similar trend was observed in vitamin $A$ and $\beta$-carotene concentrations in plasma and milk of primiparous and multiparous cows, although dietary $\beta$-carotene level was not clarified. These results suggest that there is a close relationship between vitamin $A$ and $\beta-$ carotene status of cows during early lactation.

There were no metabolic and reproductive disorders in primiparous and multiparous cows during early lactation, but the abortion and death occurred in primiparous cows at 4 months postpartum. The reason for the abor. tion and death is not clear, but compared to multiparous cows, the concentrations of plasma $\mathrm{Mg}, \mathrm{Fe}, \mathrm{Zn}$, vitamin $\mathrm{A}$, and $\beta$-carotene of primiparous cows were lower. Immunity and animal health are impaired by in. adequacies in some minerals and vitamins, including $\mathrm{Fe}, \mathrm{Zn}, \mathrm{Cu}$, vitamin $\mathrm{A}$ and $\beta$-carotene, which are required for antioxidant defences). Thus, it is possible that the health status of primiparous cows was adversely affected by the low plasma concentrations of $\mathrm{Fe}, \mathrm{Zn}$, vitamin $A$ and $\beta$-carotene, but further study is needed to clarify the effect of mineral and vitamin status on the immunity of lactating cows. 


\section{Acknowledgement}

The authors wish to thank H. SHISHIDo and A. ABE for their guidance and cooperation, and the staff of Koibuchi College of Agriculture for assistance in sample collection.

\section{References}

1) Agriculture, Forestry and Fisheries Research Council Secretariat, Japanese Feeding Stand. ard for Dairy Cattle. Chuouchikusankai. Tokyo. 1988.

2) CHEW, B.P., Vitamin $A$ and $\beta$-carotene on host defence. J. Dairy Sci., 70 : 2732-2743. 1987.

3) Foley, J.A. and D.E. OtTerBy, Availability, storage, treatment, composition, and feeding value of surplus colostrum. a review. J. Dairy Sci., $61: 1033-1060.1978$.

4) Horst, R.L., Regulation of calcium and phosphorus homeostasis in the dairy cow. J. Dairy Sci., 69 : 604-616. 1986.

5) HURLEY, W.L. and R.M. DOANE, Recent developments in the roles of vitamins and minerals in reproduction. J. Dairy Sci., 72 : 784-804. 1989.

6) Kume, S., S. TAKahashi, M. Kurihara and T. AII, The effects of heat stress on milk yield, milk composition, and major mineral content in milk of dairy cows during early lactation. Jpn. J. Zootech. Sci., $62:$ 627-632. 1990.

7) Kume, S. and S. TANABE, Effect of parity on colostral mineral concentration of Holstein cows and value of colostrum as a mineral source for newborn calves. J. Dairy Sci., 76 : 1654-1660. 1993.

8) Kume, S. and S. Tanabe, Effect of parity of Holstein cows on vitamin $A$ and $\beta$-carotene concentrations of colostrum and calf serum. Anim. Sci. Technol. (Jpn.)., 64 : 987-991. 1993.

9) Miller, J.K., E. BrezEZINSKa-SlebodZinsKa and F.C.MADSNE, Oxidative stress, antioxidants and animal function. J. Dairy Sci., $76: 2812-2823$. 1993.

10) National Research Council. Nutrient Requirements of Dairy Cattle. 6th. rev. ed. Natl. Acad. Sci., Washington, DC. 1988.

11) SAS User's Guide : Statistics, Version 6.03 Edition. SAS Inst., Inc., Cary, NC. 1988.

12) Shappell, N.W., J.H. Herbin, L.J. Deftos and R. J. AiELLO. Effects of dietary calcium and age on parathyroid hormone, calcitonin and serum and milk minerals in the periparturient dairy cows. J. Nutr., 117 : 201-207. 1987. 


\title{
ホルスタイン種乳牛の泌乳前期におけるミネラル およびビタミン栄養に及ぼす産次の影響
}

\author{
久米新一・山本英治* · 工藤徹郎 ${ }^{*} \cdot$ 田辺 忍
}

脤林水産省畜産試験場, 茨城県筑波農林研究団地 305

*鯉淵学園, 茨城県内原町 319-03

\begin{abstract}
分婏直後から泌乳前期における乳牛のミネラルおよびビタミン栄鳌に及ぼす産次の影響を明らかにす るために，初産牛 4 頭および経産牛 4 頭から秏招よび血漿を分婏後 10 週間採取した. 分婏直後における

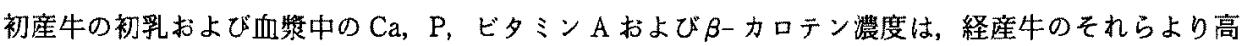
かった. 分婏直後における初産牛の初乳中 Zn 含量は経産牛のそれより高かったが, 血墏中の $\mathrm{nn}$ 濃度は

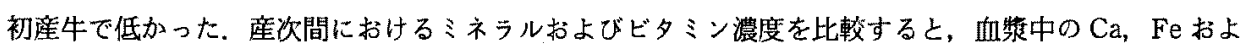
び $\mathrm{Zn}$ 濃度は分婏直後と必乳前期で同じ傾向が認められたのに対して，乳中のCa 招よびビ夕ミン A 含

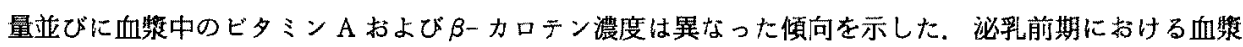
中のミネラル蕽度の変動には明確な㑯向は認められなかったが, 経産牛の血墏中ビタミンA および $\beta$ カロテン嶩度は分婏直後から泌乳前期にかけて急激に增加した。
\end{abstract}

日畜会報, $66(6): 506-512,1995$ 